\title{
Isolation and determination of bacterial microbiota of Varroa destructor and isolation of Lysinibacillus sp. from it
}

\author{
Mehtap Usta* (1)
}

\begin{abstract}
Background: The importance of bees for environmental health is known. Within the scope of this importance, it is of great importance to protect the health of bees and to prevent colony extinction. In this context, it is very important to develop effective methods in combating microorganisms, parasitoids, mites and organisms that cause disease or harm in bees. Both use different methods in terms of bee health.

Result: In this study, the possibility of the bacteria isolated from Varroa destructor mite being bioinsecticide was investigated. Accordingly, six bacteria were isolated from the mite. Isolated bacteria were analyzed according to biochemical tests, molecular analysis, optimum growth $\mathrm{pH}$ and phylogenetic tree drawn as Pantoea dispersa (GV1), Lysinibacillus macroides (GV3), Bacillus mycoides (GV4), Lysinibacillus fusiformis (GV5), Pseodomonas lutea (GV5), Lysinibacillus varians (GV7). Lysinibacillus sp. The entomopathogenic feature of Lysinibacillus sp. ranked it as the most important species. When the insecticidal properties of bacteria were examined, they were determined as 53, 90, 62, 95, 74 and 83\% for GV1, GV3, GV4, GV5, GV6 and GV7, respectively.

Conclusion: Based on these results and literature review, Lysinibacillus sp. species had a high potential to be used as bioinsecticide against $V$. destructor mite.
\end{abstract}

Keywords: Varroa destructor, Honey bee, Bacteria, Microbiology, Biological control

\section{Background}

Beekeeping makes significant contributions to the agricultural economy in Turkey and in the world. It is evaluated that vegetative production can be reduced by $47 \%$ in an environment where there are no bees. Colony extinction events, which have recently been observed in different countries and whose cause cannot be explained, are considered as a problem that may affect the biological balance in the future. It is noted that similar problems can be seen in Turkey. Viral, bacterial, parasitic and fungal diseases seen in honey bees are very important for the honey production sector. It is known that the rate of co-infection of honey bee colonies with colony extinction

${ }^{*}$ Correspondence: myakupoglu@gmail.com

Tonya Vocational School, Trabzon University, Trabzon, Turkey with viral and parasitic pathogens is higher than the rate of coexistence of other pathogens (Berényi et al. 2006). For this reason, many studies have been conducted to determine these diseases that cause economic efficiency losses. However, as a result of these studies, no medicine or therapeutic product for diseases could be obtained. Bacteria, fungi, viruses, parasitoids and protozoans in honey bees cause diseases in adults and juvenile bees. These diseases cause slow development of bees and limitation of their effective production and even extinction of hives (Williams 2000). Bee colonies are exposed to various agro-ecosystems throughout the year and to many environmental variables that can affect the microbial balance of the hive. Bee microflora is depended on different factors such as seasonal and geographical changes (Mattila et al. 2012), developmental stages from fertilized egg to adulthood (Martinson et al. 2012), honey 
bee's age, nutrition and social life style (Linjordet 2016). Some studies show that as worker bees age and forage, their microbiota compositions shift slightly to different species (Saccà and Lodesani 2020). Varroosis, a parasitic disease, constitutes the biggest problem among these diseases. $V$. destructor is an external parasite that survives and reproduces in the colonies of bees and is highly harmful to beekeeping. Today, the disease that harms the world beekeeping the most is Varroosis (Williams 2000). Many studies have been conducted on the biology, epidemiology, parasitoid guest relations, population dynamics and hormonal, chemical, physical, genetic and biological struggles of Varroa destructor (Acari: Varroidae), and protection and control methods against $V$. destructor have been tried to be developed. One of the integrated control methods in many parts of the world in beekeeping; biotechnical methods, various organic acids, essential oils and the use of chemical substances together have started to be applied as combat methods (Škerl et al. 2011). Many researchers emphasized and advocated methods of combating $V$. destructor from colonies without using chemicals. Due to the intensive use of chemicals, residue problem in honey is one of the most important problems. Pesticides have many disadvantages such as the problem of residue as a result of polluting the environment and the deterioration of biological balance due to resistance to these chemicals. Most of these pesticides are used in $V$. destructor control. Today, organic acids, vegetable oils or mechanical methods are used for $V$. destructor control. In addition to these, the use of biological control methods should be preferred because they will be less harmful. Since $V$. destructor damages the colony by carrying viruses, its struggle is of great importance.

The aim of this study was to determine an effective screening method for mite detection in natural infested honeybee colonies with $V$. destructor, whose residue and resistance risk is low and will not adversely affect human health. For this purpose, bacteria were isolated from $V$. destructor and defined.

\section{Methods}

\section{Sample collection}

Samples of $V$. destructor mites from Apis mellifera were collected from hives located in Gümüşhane province, distinct of Kürtün and village of Günyüzü, Turkey (latitude 40.748302 and longitude 38.984703). The hives used didn't receive chemical applications. The samples were obtained using around 250 pieces $V$. destructor obtained from honey bees collected from approximately 20 hives. The collected $V$. destructor mites were placed in sterile tubes and transferred to the laboratory. The samples were collected twice a year, in the spring (May 2020) and the autumn (October 2020).

\section{Isolation of bacteria}

Before bacterial isolation, $V$. destructor mites were surface sterilized by $70 \%$ alcohol to remove possible contamination and then washed in sterile distilled water. The mite bodies were homogenized in $0.5 \mathrm{ml}$ of sterilized phosphate buffer solution (0.01 M PBS, $\mathrm{pH} 7.4$ ) using a glass tissue grinder and filtered twice through 2 layers of cheesecloth to remove debris. After preparing the homogenate for bacterial isolation, suspensions were diluted to $1 \times 10^{-5}$ and $0.1 \mathrm{ml}$ were spread on nutrient agar (Thiery and Frachon 1997). Plates were incubated at $30{ }^{\circ} \mathrm{C}$ for $2-3$ days. Isolates were determined based on color and morphology of the colonies. Individual colonies were isolated, sub-cultured twice to ensure purity and then stored in 15\% sterilized glycerol at $-80{ }^{\circ} \mathrm{C}$ for further studies. Pure cultures of bacterial colonies were identified by their morphology, spore formation, physiological, biochemical and molecular characteristics (16S rRNA).

\section{Morphological, physiological, biochemical characterizations and scanning electron microscope of Isolates}

Bacterial strains were selected based on their morphological biochemical, physiological features according to Bergey's Manual of Systematic Bacteriology (Sneath 1986). Phenotypic characteristics of the strains included cell and colony shape on NA. Optimum $\mathrm{pH}$ was determined, after $16 \mathrm{~h}$ incubation at $30^{\circ} \mathrm{C}$ by measuring the densities using a spectrophotometer (Spectramax M2) at OD600 (Ben-Dov et al. 1995). Biochemical panel test system API 20E (bioMerieux, France) was handled according to the manufacturer's instructions. Then the panels were incubated for $18-24 \mathrm{~h}$ at $30{ }^{\circ} \mathrm{C}$. The results of these tests were performed by referring to the API $20 \mathrm{E}$ reading table.

The bacterial samples (Lysinibacillus sp.) were grown on NA for $24 \mathrm{~h}$ at $30^{\circ} \mathrm{C}$ on $20 \mathrm{ml}$ nutrient agar. The bacteria were collected by sterile inoculating loops solid culture plate. The collected samples were added into $1 \mathrm{ml}$ deionized water, vortexed and centrifuged for $5 \mathrm{~min}$ at $7500 \mathrm{rpm}$. The supernatant was discarded. This procedure was repeated 3 times. Finally, the washed bacteria were diluted 20 times with sterile water. Then, $5 \mu \mathrm{l}$ of the bacteria solution was spotted and dried on a scanning electron microscope (SEM) specimen stub (Carl Zeiss, Germany). The accelerating voltage was in the range of $5-10 \mathrm{kV}$. 


\section{S rRNA gene sequence analysis}

Genomic DNA from all samples was extracted using the standard phenol/chloroform procedures (Sambrook et al. 1989). PCR amplification of $16 \mathrm{~S}$ rRNA genes of bacterial isolates was performed with the following universal primers (William et al. 1991); UNI 16S-L: 5_- ATT CTAGAGTTTGATCATGGCTCA-3_ as forward and UNI 16S-R: 5_ ATGGTACCGTGTGTGACGGGCGGT G TGTA-3_ as reverse. PCR conditions were adjusted according to William et al. (1991). Reactions were totally in $50 \mu \mathrm{l} ; 1 \mu \mathrm{l}$ of template DNA was mixed with $5 \mu \mathrm{l}$ reaction buffer, $0.2 \mathrm{mM}$ of each deoxynucleoside triphosphate (dNTP), $0.5 \mu \mathrm{M}$ (each) with primer and $0.5 \mathrm{U}$ with Taq DNA polymerase. Amplification was performed with 30 cycle program (each cycle consisting of denaturation at $94{ }^{\circ} \mathrm{C}$ for $3 \mathrm{~min}$, annealing at $55^{\circ} \mathrm{C}$ for $60 \mathrm{~s}$ and extension at $72{ }^{\circ} \mathrm{C}$ for $3 \mathrm{~min}$ ), followed by a final extension step at $72{ }^{\circ} \mathrm{C}$ for $5^{\circ} \mathrm{min}$, by using thermal cycler (BioRad). Each experiment was associated with negative (without DNA template) controls. PCR products were analyzed on a $1.2 \%$ agarose gel. The samples displayed on the gel were sent to the sequence after cleaning from the gel. Sequence analysis of the samples of $16 \mathrm{~S}$ rRNA products was performed using $16 \mathrm{~S}$ universal primers by SenteBiolab (Ankara/TURKEY). Obtained sequences were used to perform BLAST searches using the NCBI GenBank database. Comparison of approximately $1.400 \mathrm{bp}$ fragments of 16S rRNA gene sequences of each isolate with other $16 \mathrm{~S}$ rRNA sequences in the NCBI GenBank database (Altschul et al. 1990) was performed.

\section{Phylogenetic relationship of the bacterial ısolates}

The sequences obtained were used to perform BLAST searches using the NCBI GenBank database to confirm isolate identification (Altschul et al. 1990). Evolutionary relationships of the six bacterial isolates were evaluated. Cluster analyses of the sequences were performed using BioEdit (version 7.09) with Clustal W, followed by neighbor joining analysis on aligned sequences performed with MEGA 7.0 software (Tamura et al. 2013). Reliability of dendograms was tested by bootstrap analysis with 1000 replicates using MEGA 7.0.

\section{Determination of toxin genes}

Toxin genes were investigated according to the methodology described by Nishiwaki et al. (2007). PCR amplification was performed of the toxin genes using binary toxin genes, $m t x 1$ and $m t x 2$. Toxin gene primers are given in Table 1. PCR was constructed according to the following conditions: pre-amplification $94{ }^{\circ} \mathrm{C}$ for $3 \mathrm{~min}$, followed by 30 cycles of denaturation at $94{ }^{\circ} \mathrm{C}$ for $30 \mathrm{~s}$, annealing at $55{ }^{\circ} \mathrm{C}$ for $60 \mathrm{~s}$ and elongation at $72{ }^{\circ} \mathrm{C}$ for
Table 1 Primers used for toxin gene sequencing

\begin{tabular}{ll}
\hline Toxin gene primers & Primer sequence $\left(\mathbf{5}^{\prime} \boldsymbol{\rightarrow} \mathbf{3}^{\prime}\right)$ \\
\hline$M t \times 1 F$ & CAAGCTGCTTCACTTACATG \\
$M t \times 1 R$ & GTCCAGTTACATCTTGAGCC \\
$M t \times 2 F$ & GGAGACTAATTGAATTTTCGGTTTCC \\
$M t \times 2 R$ & GCGATGCTGGGCTATGTTCGTTGTTA \\
\hline
\end{tabular}

$3 \mathrm{~min}$. Reactions were totally in $50 \mu \mathrm{l} ; 1 \mu \mathrm{l}$ of template DNA was mixed with $5 \mu$ reaction buffer, $0.2 \mathrm{mM}$ of each deoxynucleoside triphosphate (dNTP), $0.5 \mu \mathrm{M}$ (each) with primer and $0.5 \mathrm{U}$ with Taq DNA polymerase. PCR products were analyzed on a $1.2 \%$ agarose gel.

\section{Miticidal effects of bacteria}

All of the bacterial isolates were tested as overnight cultures after removing the growth medium (NB). Bacterial isolates were incubated for $18 \mathrm{~h}$ (72 $\mathrm{h}$ for sporulation) at $30{ }^{\circ} \mathrm{C}$ in the nutrient broth medium (NB). After incubation, bacterial cells were centrifuged at $3000 \mathrm{rpm}$ for $10 \mathrm{~min}$ (Ben-Dov et al. 1995). The pellet was resuspended by adding sterile PBS. The optical density of the cells was adjusted to 1.89 at OD (optical density) 600 (Moar et al. 1995).

Concentration-response assays of bacterial cultures against $V$. destructor and their impact on honey bee larvae. Adult females of $V$. destructor were collected from recently capped brood cells and placed in Petri dishes (35 $\mathrm{mm}$ diameter $\times 10 \mathrm{~mm}$ high) which had previously been filled with sterile and residue free wax. According to the trial, mites were sprayed or immersed by spent bacterial culture of each strain (GV1, GV3, GV4, GV5, GV6 and GV7). Each trial was carried out with 3 replicates. The application was done with a small spray dispenser flask or the mites were immersed in a test tube. Then, mites were left for $2 \mathrm{~h}$ before being fed with spinning larvae. Larvae of $A$. mellifera subspecies (one every 2 mites) were used in substituted every 48 or $24 \mathrm{~h}$ in case of need. The trial dishes were incubated at $26{ }^{\circ} \mathrm{C}$ and $70 \% \mathrm{RH}$, in the dark (Lodesani et al. 2017). Observations were carried out every $24 \mathrm{~h}$ in order to count and collect the dead mites, until at least $90 \%$ of the mites were dead. Each dish contained 4 mites and 2 larvae.

\section{Results}

In this study, 6 bacterial isolates; Pantoea dispersa (GV1), Lysinibacillus sp. (GV3), Bacillus mycoides (GV4), Lysinibacillus fusiformis (GV5), Pseudomonas sp. (GV6) and Lysinibacillus sp. (GV7) from were isolated and characterized from $V$. destructor. The colony colors of 5 isolates were creamy, and the other isolate was yellow. The 
Table 2 Optimum pH range of bacteria

\begin{tabular}{lllllll}
\hline pH & GV1 & GV3 & GV4 & GV5 & GV6 & GV7 \\
\hline $\mathrm{pH} 3$ & - & - & - & - & - & - \\
$\mathrm{pH} 4$ & - & - & - & - & - & - \\
$\mathrm{pH} 5$ & - & - & + & + & + & + \\
$\mathrm{pH} 6$ & + & + & + & + & + & + \\
$\mathrm{pH} 7$ & + & + & + & + & + & + \\
$\mathrm{pH} 8$ & + & + & + & + & + \\
$\mathrm{pH} 9$ & + & + & + & & + \\
$\mathrm{pH} 10$ & & + & + & + \\
\hline
\end{tabular}

Table 3. 165 results of bacteria

\begin{tabular}{llll}
\hline Isolate name & Bacterium name & $\begin{array}{l}\text { Accession } \\
\text { number }\end{array}$ & Similarity (\%) \\
\hline GV1 & $\begin{array}{l}\text { Pantoea dispersa } \\
\text { Lysinibacillus } \\
\text { macroides }\end{array}$ & MW940887 & 99 \\
GV3 & MW940888 & 99 \\
Gacillus mycoides & MW940889 & 99 \\
GV5 & $\begin{array}{l}\text { Lysinibacillus } \\
\text { fusiformis }\end{array}$ & MW940890 & 99 \\
GV6 & $\begin{array}{l}\text { Pseudomonas lutea } \\
\text { Lysinibacillus var- }\end{array}$ & MW940891 & 99 \\
GV7 & MWans & & 99 \\
& & &
\end{tabular}

optimum $\mathrm{pH}$ range for the bacterial isolates was determined (Table 2).

$16 \mathrm{~S}$ rRNA gene sequence analysis results of the isolates are given in Table 3 . The $16 \mathrm{~S}$ rRNA partial gene sequences generated in this study have accession numbers MW940887, MW940888, MW940889, MW940890, MW940891 and MW940892, respectively.

GV3, GV5 and GV7 are identified as Lysinibacillus sp. and these are the first record from $V$. destructor. Scanning electron microscope images of these bacteria are shown in Fig. 1. Also, GV1 was identified as Pantoea dispersa and this is first record from $V$. destructor.

Phylogenetic tree was constructed by using neighbor joining method (Fig. 2). The similarities between isolates ranged between 93 and 100\% compared to other species.

Based on the studies, isolates were identified as Pantoea dispersa (GV1), Lysinibacillus sp. (GV3), Bacillus mycoides (GV4), Lysinibacillus fusiformis (GV5), Pseudomonas sp. (GV6) and Lysinibacillus sp. (GV7) (Fig. 1). These identifications were also confirmed by phylogenetic analysis of the bacterial isolates and their closely related species based on the $16 \mathrm{~S}$ rRNA sequence (Fig. 2).

In this study, PCR amplification of $\mathrm{mtx}$ toxin genes ( $m t x 1$ and $m t x 2$ ) of all bacteria was scanned. According to amplification results, only B. mycoides (GV4) (Lane 3) had $m t x 1$ gene (Fig. 3). The other five bacteria did not have both $m t x 1$ and $m t x 2$ genes.

As a result of the bioassay study, the highest rate (90, 95 and 83\%) was observed in bacteria of the genus Lysinibacillus spp., which were the bacteria named: GV3, GV5 and GV7, respectively, within 10 days. Other bacteria also showed mortality rates of 53, 62 and $74 \%$ respectively (GV1, GV4 and GV6), within 10 days (Fig. 4). Mites sizes were $1.5 \mathrm{~mm}$ long and $1.7 \mathrm{~mm}$ wide. Observations were carried out every $24 \mathrm{~h}$ in order to count and collect the dead mites, until at least $90 \%$ of the mites were dead. In all the trials, the comparison took place between the uninoculated culture broth (control) and the bacteria culture (treatment). Each dish contained 4 mites and 2 larvae.

\section{Discussion}

In the present study, a culturable bacterial microbiota of $V$. destructor was determined to identify new candidate organisms as a possible biocontrol agents against the pest. Four different genera of bacteria were isolated. These are Pantoea, Lysinibacillus, Bacillus and Pseudomonas. And also 2 species (Lysinibacillus sp. and Pantoea dispersa) were determined for the first time from $V$. destructor. Lysinibacillus sp. is a naturally occurring, mesophilic, soil bacterium, toxic to insects. It was isolated from the dead larvae of Culex pipiens and Palomena prasina in previous studies and investigated on the pathogenicity of the isolated hosts. (Ozsahin et al. 2014) Insecticidal property of this organism is due to 2 proteins produced during sporulation. These proteins are the binary toxins, which accumulate as crystal inclusions and mosquitocidal toxins (Mtx proteins) are produced during vegetative growth of the bacteria. The bacteria are not harmful to humans and other animals, Lysinibacillus sp. is an ideal insecticide.

The insecticidal bacterium that has been in trade and has grown in importance in the last decade is $B$. sphaericus, with many isolates proven to be active against mosquito larvae. B. sphaericus strains first described as 

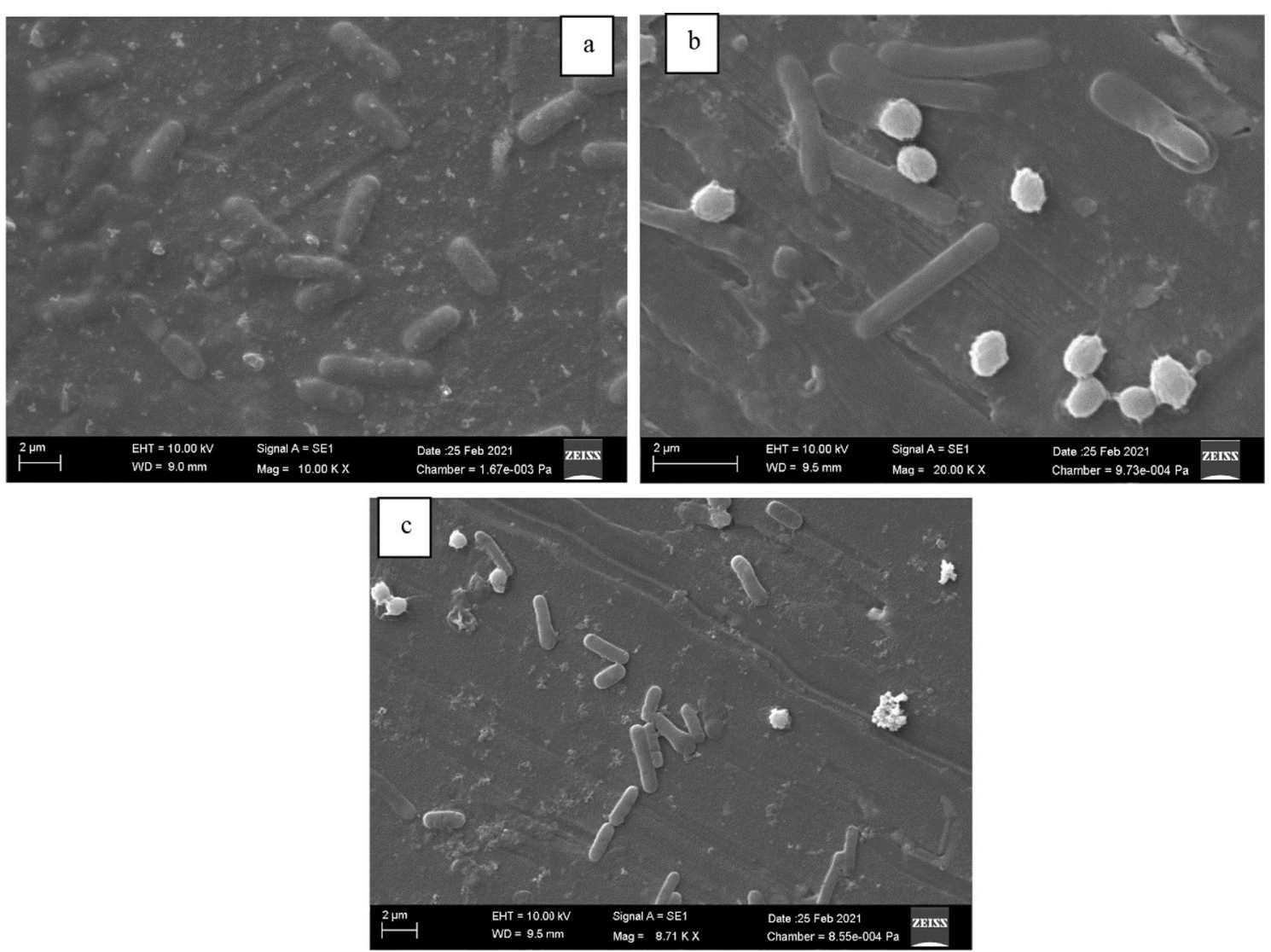

Fig. 1 Scanning electron microscope images of the bacteria GV3 (a), GV5 (b) and GV7 (c)

insect pathogens in 1965. Although this discovery led to further investigation of the bacterium, until 1973 it was not that species with potential use in insect control programs were discovered. (Singer 1973).

The genus Pantoea is a diverse group of yellow pigment, rod-shaped Gram-negative bacteria in Enterobacteriaceae. Some Pantoea isolates produce antimicrobials and have been developed as commercial biocontrol products The ubiquity, versatility and genetic traceability of Pantoea isolates make it an ideal group not only for exploring niche-specific adaptation and opportunism, but also for the development of commercially relevant medicinal, agricultural and environmental products. A wide variety of insect species appear to be associated with different Pantoea isolates (Jiang et al. 2019). Many of these relationships have been described mutually, where bacteria are found in specialized cells of the symbiont host in the insect intercellularly and in some cases intracellularly (Vorwerk et al. 2007). In such mutualisms, it has been suggested that the insect host can provide food and habitat to bacteria and possibly provide a direct propagation pathway (Sood and Nath 2002), while the insect may benefit from bacterial-mediated hydrolysis of proteins (Sood and Nath 2002), antagonism of pathogens (Vorwerk et al. 2007), breakdown of toxic substances (Sood and Nath 2002), nitrogen fixation, nutrition and digestion (Maccollom et al.2009). Bacillus mycoides has lower GC and a gram positive bacteria than its old phylogeny. It is a spore-forming rod that produces a characteristic spreading filament morphology when cultured on agar. B. mycoides is found in soils all over the world. (Ko et al. 2004). The closest relatives of B. mycoidesthe Bacillus cereus subgenus-are human pathogens (B. cereus, B. anthracis) and other animals, including insects (B. anthracis) (B. thurigiensis) (Ko et al. 2004). $B$. mycoides was known since 1886 when the spreading rhizoidal colony structure was first observed by Flu"gge in soil cultures (Flugge 1886). B. mycoides is considered a saprophytic organism that makes it ecologically distinct from its more pathogenic close relatives (Nakamura and Jackson 1995).

Microflora associated with honey bees was first investigated as techniques developed (Gilliam and Valentine 1976; Gilliam and Morton 1978). In various studies, Gram-variable pleomorphic bacteria, Bacillus species and some Enterobacteriaceae family members were find 


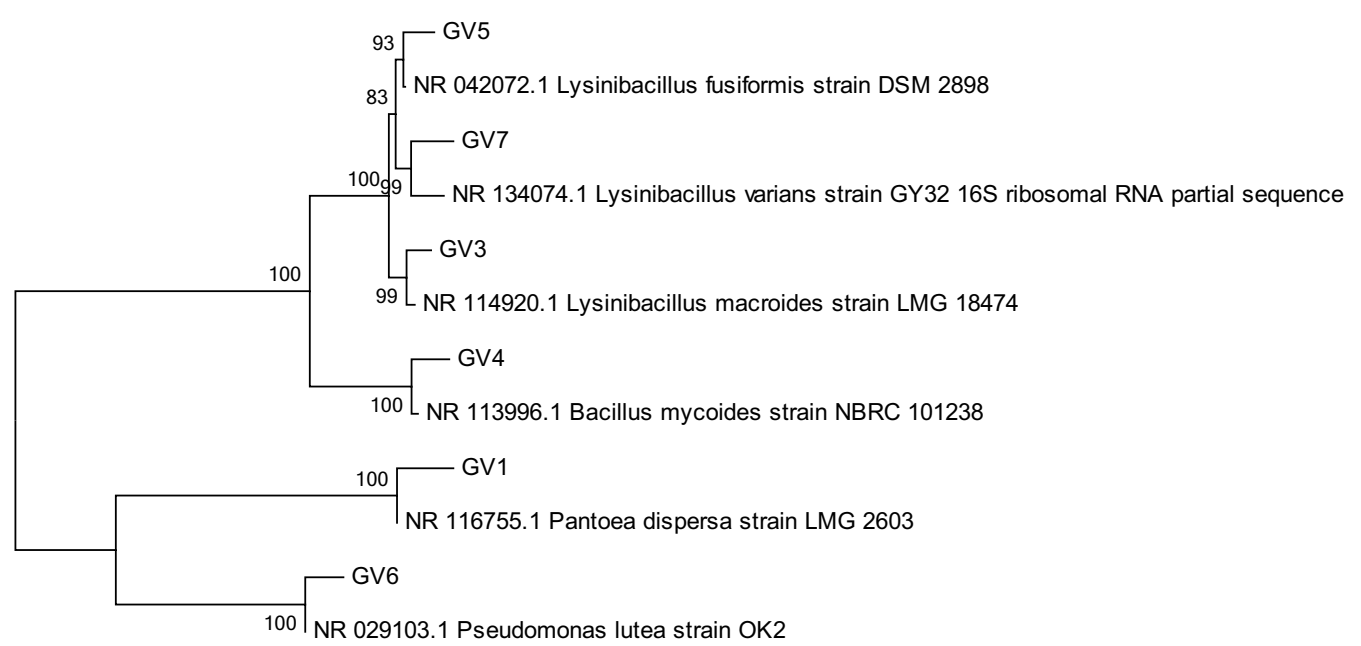

$$
\stackrel{\longmapsto}{\longmapsto .020}
$$

Fig. 2 Evolutionary relationships of taxa. The evolutionary history was inferred using the neighbor joining method (Saitou and Nei 1987). The optimal tree with the sum of branch length $=0.45843344$ is shown. The percentage of replicate trees in which the associated taxa clustered together in the bootstrap test (1000 replicates) are shown next to the branches (Felsenstein 1985). The tree is drawn to scale, with branch lengths in the same units as those of the evolutionary distances used to infer the phylogenetic tree. The evolutionary distances were computed using the maximum composite likelihood method (Tamura et al. 2004) and are in the units of the number of base substitutions per site. The analysis involved 12 nucleotide sequences. Codon positions included were $1 s t+2 n d+3 r d+$ Noncoding. All positions containing gaps and missing data were eliminated. There were a total of 1298 positions in the final dataset. Evolutionary analyses were conducted in MEGA7 (Kumar et al. 2016)

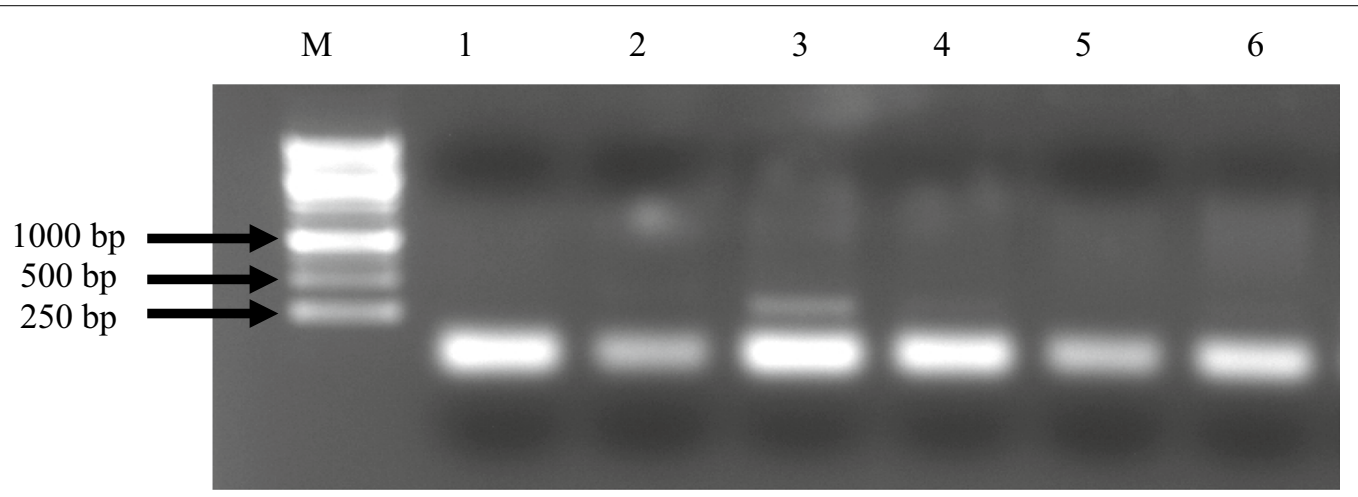

Fig. 3 PCR amplicon of $m t x 1$ toxin genes of all bacteria. 1: GV1, 2: GV3, 3: GV4, 4: GV5, 5: GV6, 6: GV7. Bacillus mycoides (Lane 3: the size of band is approximately $300 \mathrm{bp}$ )

on pollen, nectar, bees, honey, beeswax and royal jelly (Suyabatmaz et al. 2020).

Also $V$. destructor mites control is very important for honey bee viruses diseases. $V$. destructor is a vector for various honey bee viruses. Additionally, Varroa mites may induce immunosuppression in parasitized pupae and, thus, activate these covert virus infections (Noël et al. 2020). By feeding on bee tissues, Varroa acts as an efficient vector of pathogens. Vector-based disease transmission involves three main phases: Acquisition: varroa feed on bee tissues, ingesting the pathogens that reside in those tissues, Mobility: varroa moves freely between different individual hosts, Transmission: during feeding, varroa introduces the pathogen into the new host (Traynor et al. 2020; Light et al. 2020).

\section{Conclusions}

According to the results of the study, the bacteria belonging to the genus Lysinibacillus are potentially entomopathogenic as well as an effective bioinsecticide on many pests, especially $V$. destructor mite. It should be tested on different pests, especially bee pests. This study 


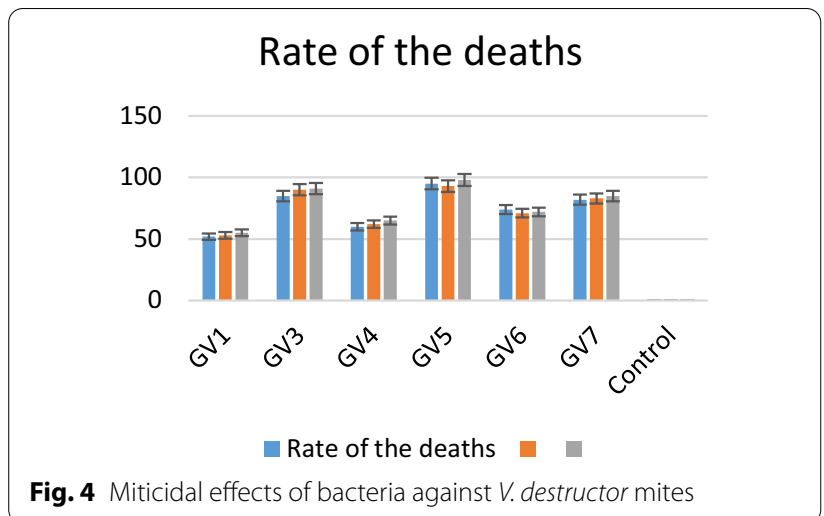

showed that the bacterium belonging to the genus Lysinibacillus was isolated for the first time from $V$. destructor. It is thought that a more advanced commercial preparation can be prepared by carrying out bioinsecticide studies with this bacterium. Thus, in addition to the currently used B. thrugiensis isolates, different preparations can also be applied.

\section{Abbreviations}

PCR: Polymerase chain reaction; OD: Optical density; SEM: Scanning electron microscope.

\section{Acknowledgements}

This work has been supported by Trabzon University Scientific Research Projects Coordination Unit under grant number 21HZP00159.

\section{Authors' contributions}

Author(s) contributed equally. All authors read and approved the final manuscript.

\section{Funding}

This work has been supported by Trabzon University Scientific Research

Projects Coordination Unit under grant number 21HZP00159.

\section{Availability of data and materials}

Not applicable.

\section{Declarations}

Ethics approval and consent to participate

Ethics certificate is not required in the study.

\section{Consent for publication}

Not applicable.

\section{Competing interests}

There is no disagreement between the Author/Authors.

Received: 28 June 2021 Accepted: 14 October 2021

Published online: 26 October 2021

\section{References}

Altschul SF, Gish W, Miller W, Myers EW, Lipman DJ (1990) Basic local alignment search tool. J Mol Biol 215(3):403-410. https://doi.org/10.1016/500222836(05)80360-2 (PMID: 2231712)
Ben-Dov E, Boussiba S, Zaritsky A (1995) Mosquito larvicidal activity of Escherichia coli with combinations of genes from Bacillus thuringiensis subsp. israelensis. J Bacteriol 177:2581-2587

Berényi O, Bakonyi T, Derakhshifar I, Köglberger H, Nowotny N (2006) Occurrence of six honey bee viruses in diseased Austrian Apiaries. Appl Environ Microbiol 72:2414-2420

Felsenstein J (1985) Confidence limits on phylogenies: an approach using the bootstrap. Evolution 39:783-791

Flugge C (1886) Die mikroorganismen. FCW Vogel, Leipzig

Gilliam M, Morton LH (1978) Bacteria belonging to the genus Bacillus isolated from honeybees, Apis mellifera, fed 2,4-D and antibiotics (1). Apidologie 9(3):213-222

Gilliam M, Valentine DK (1976) Bacteria isolated from the intestinal contents of foraging worker honeybees, Apis mellifera: the genus Bacillus. J Invertebr Pathol 28(2):275-276. https://doi.org/10.1016/0022-2011(76)90137-3

Jiang L, JeongJC LJS, Park JM, Yang JW, Lee MH, Choi SH, Kim CY, Kim DH, Kim SW, Lee J (2019) Potential of Pantoea dispersa as an effective biocontrol agent for black rot in sweet potato. Sci Rep 9(1):16354. https://doi.org/10. 1038/s41598-019-52804-3 (PMID: 31704990; PMCID: PMC6841936)

Ko KS, Kim JW, Kim JM, Kim W, Chung IJ (2004) Population structure of the Bacillus cereus group as determined by sequence analysis of six housekeeping genes and the plcR gene. Infect Immun 72:5253-5261

Kumar S, Stecher G, Tamura K (2016) MEGA7: molecular evolutionary genetics analysis version 7.0 for bigger datasets. Mol Biol Evol 33(7):1870-1874. https://doi.org/10.1093/molbev/msw054

Light M, Shutler D, Cutler GC (2020) Varroa destructor mite electrophysiological responses to honey bee (Apis mellifera) colony volatiles. Exp Appl Acarol 81:495-514. https://doi.org/10.1007/s10493-020-00519-w

Linjordet SM (2016) A comparative analysis of lactic acid bacteria Isolated from honeybee gut and flowers, with focus on phylogeny and plasmid profile. Master Thesis. Norwegian University of Life Sciences, Department of Chemistry, Biotechnology and Food Science, Norvec, 37 s, pp 1-3, 18-20

Lodesani M, Costa C, Franceschetti S, Bergomi P, Galaverna G, Dall'Asta C (2017) Toxicity of destruxins against the parasitic mite Varroa destructor and its host Apis mellifera. J Apic Res 56:278-287. https://doi.org/10.1080/00218 839.2017.1304611

Maccollom G, Lauzon C, Sjogren R (2009) Association and attraction of blueberry maggot fly curran (Diptera:Tephritidae) to Pantoea (Enterobacter) agglomerans. Environ Entomol 38:116-120

Martinson VG, Moy J, Moran N (2012) Establishment of characteristic gut bacteria during development of the honeybee worker. Appl Environ Microbiol 78:2830-2840 ([PubMed: 22307297])

Mattila HR, Rios D, Walker-Sperling VE, Roeselers G, Newton ILG (2012) Characterization of the active microbiotas associated with honeybees reveals healthier and broader communities when colonies are genetically diverse. PLoS ONE 7:e32962. https://doi.org/10.1371/journal.pone.00329 62

Moar WJ, Pusztzai-Carey M, Mack TP (1995) Toxity of purified proteins and the HD-1 strain from Bacillus thuringiensis againts lesser cornstalk borer (Lepidoptera: Pyralidae). J Econ Entomol 88:606-609

Nakamura L, Jackson M (1995) Clarification of the taxonomy of Bacillus mycoides. Int J Syst Bacteriol 45(1):4-7

Nishiwaki H, Nakashima K, Ishida C, Kawamura T, Matsuda K (2007) Cloning, functional characterization, and mode of action of a novel insecticidal pore-forming toxin, sphaericolysin, produced by Bacillus sphaericus. Appl Environ Microbiol 73(10):3404-3411

Noël A, Le Conte Y, Mondet F (2020) Varroa destructor: how does it harm Apis mellifera honey bees and what can be done about it? Emerg Top Life Sci 4(1):45-57. https://doi.org/10.1042/ETLS20190125 (PMID: 32537655; PMCID: PMC7326341)

Ozsahin E, Sezen K, Demir I, Demirbag Z (2014) Bacterial isolates from Palomena prasina (Hemiptera: Pentatomidae) include potential microbial control agents. Biocontrol Sci Technol 24:1039-1051

Saccà ML, Lodesani M (2020) Isolation of bacterial microbiota associated to honey bees and evaluation of potential biocontrol agents of Varroa destructor. Benef Microbes 11(7):641-654

Saitou N, Nei M (1987) The neighbor-joining method: a new method for reconstructing phylogenetic trees. Mol Biol Evol 4:406-425

Sambrook J, Fritsch EF, Maniatis T (1989) Molecular cloning: a laboratory manual. Cold Spring Harbor Laboratory Press, Cold Spring Harbor 
Singer S (1973) Insecticidal activity of recent bacterial isolates and their toxins against mosquito larvae. Nature 244:110-111

Škerl MIS, Nakrst M, Žvokelj L, Gregorc A (2011) The acaricidal effect of flumethrin, oxalic acid and amitraz against Varroa destructor in honey bee (Apis mellifera carnica) colonies. Acta Vet Brno 80:51-56

Sneath PHA (1986) Regular, nonsporing gram positive rods. In: Sneath PHA, Mair NS, Sharpe ME, Holt JG (eds) Bergey's manual of systematic bacteriology, vol 2. Williams and Wilkins, Baltimore, pp 1208-1260

Sood P, Nath A (2002) Bacteria associated with Bactrocera sp.

(Diptera:Tephritidae)_isolation and identification. Pest Manag Econ Zool 10:1-9

Suyabatmaz \$̧, Bozdeveci A, Karaoğlu ŞA (2020) Bal Arılarında Gastrointestina Bakteriyel Flora (Gastrointestinal bacterial flora in honey bees). U.arı.d.-U Bee J 20(19):97-113. https://doi.org/10.31467/uluaricilik.701170

Tamura K, Nei M, Kumar S (2004) Prospects for inferring very large phylogenies by using the neighbor-joining method. Proc Natl Acad Sci (USA) 101:11030-11035

Tamura K, Stecher G, Peterson D, Filipski A, Kumar S (2013) MEGA6: molecular evolutionary genetics analysis version 6.0. Mol Biol Evol 30:2725-2729

Thiery I, Frachon E (1997) Identification, isolation, culture and preservation of entomopathogenic bacteria. In: Lacey AL (ed) Manual of techniques in insect pathology. Academic Press, London, pp 55-73
Traynor KS, Mondet F, de Miranda JR, Techer M, Kowallik V, Oddie M, Chantawannakul P, McAfee A (2020) Varroa destructor: a complex parasite, crippling honey bees worldwide. Trends Parasitol 36(7):592-606. https://doi org/10.1016/j.pt.2020.04.004 (Epub 2020 May 23. PMID: 32456963)

Vorwerk S, Martinez-Torres D, Forneck A (2007) Pantoea agglomerans associated bacteria in grape phylloxera (Daktulosphaira vitifoliae, Fitch). Agric for Entomol 9:57-64

William GW, Susan MB, Dale AP, David JL (1991) 16S ribosomal DNA amplification for phylogenetic study. J Bacteriol 173:697-703

Williams DL (2000) A veterinary approach to the European honey bee (Apis mellifera). Vet J 160(1):61-73. https://doi.org/10.1053/tvjl.2000.0474

(PMID: 10950136)

\section{Publisher's Note}

Springer Nature remains neutral with regard to jurisdictional claims in published maps and institutional affiliations.

\section{Submit your manuscript to a SpringerOpen ${ }^{\circ}$ journal and benefit from:}

- Convenient online submission

- Rigorous peer review

- Open access: articles freely available online

- High visibility within the field

- Retaining the copyright to your article

Submit your next manuscript at $\boldsymbol{\nabla}$ springeropen.com 